\title{
Letter to the Editor Obesity and related medical conditions: a role for functional foods
}

Sir,

Dietary fat intake, especially saturated fat, has long been associated with both coronary heart disease risk factors and obesity ${ }^{1,2}$. In addition, consumption of high levels of sugar and other refined carbohydrates has been reported to cause an increase in blood triglycerides ${ }^{3}$. High triglyceride levels in the blood have also been associated with coronary heart disease and hypertension ${ }^{4,5}$. Hypertension is the most common cardiovascular risk factor in the $\mathrm{USA}^{6,7}$, and a number of studies have shown unequivocally a powerful association between high blood pressure and risk of cardiovascular disease ${ }^{8,9}$. Dietary salt reduction has been recommended to reduce hypertension and cardiovascular disease mortality and morbidity $^{10,11}$.

In an attempt to reduce the impact of a negative diet on heath status, we have developed a functional food designed to reduce selected risk factors associated with obesity and coronary heart disease. A functional food is one that has demonstrated a significant effect on the body beyond adequate nutrition, in a way that improves health and well-being and reduces disease. The developed product is based on one of the UK's best-selling biscuits, which traditionally is high in both fat and sugar (hence high in energy) but contains little fibre. The first part of the study was to modify the ingredient profile of the standard product. This included increasing fibre while reducing both fat and sugar levels and removing salt to the lowest level. This was undertaken in conjunction with maintaining commercial viability.

Biscuits are traditionally high in both fat (including saturated fat) and sugar, and the biscuit market is dominated by biscuits having fat levels in excess of $20 \%$.

The base biscuit (jam not included) contains no sugar (100\% reduction) and the fat level has been reduced by $66 \%$, based on the standard product. Salt has been completely removed from the modified biscuit formulation.

A number of studies have reported an association between low dietary fibre intake and risk of coronary heart disease $^{12,13}$. The level of fibre in the modified biscuit is double that found in the standard product (3.4 vs. $1.7 \mathrm{~g}$ ). Vitamins were also added to the biscuit in an attempt to reduce plasma levels of homocysteine. Homocysteine is one of the more contemporary risk factors that have been identified as an independent risk factor for coronary heart disease ${ }^{14-16}$. Vitamin $\mathrm{B}_{6}, \mathrm{~B}_{12}$ and folic acid are factors that can modify plasma homocysteine levels ${ }^{17}$ and were added to the biscuit to help reduce homocysteine concentrations.

The second part of the study was designed to ascertain and acquire consumer acceptability, which was achieved by relevant organoleptic assessment. We used consumers who regularly ate the standard product and asked them to eat the modified and standard product in a randomised double-blind trial. No preference $(P>0.05)$ was shown for either of the biscuits, and it was concluded that the modified product was acceptable to the consumer.

The final part of the biscuit design was confirmation of the functionality of the product by biomedical assessment. This part of the study was a randomly designed, $12 \mathrm{~h}$ fasting study to measure differences in blood levels of a number of risk factors associated with heart disease. A two-way repeated analysis of variance was used for normally distributed data and the Wilcoxon matched pairs signed rank test was applied to data that were not normally distributed. We found a significant decrease in homocysteine, glucose and, surprisingly, lipoprotein(a) $(P<0.05)$ following consumption of the modified biscuit (see Table 1). The lower level of serum homocysteine is consistent with the findings of earlier reports relating to the effects of dietary folate, vitamins $\mathrm{B}_{6}$ and $\mathrm{B}_{12}{ }^{16,17}$.

We are currently investigating further the relationship between the biscuit and lipoprotein(a). We can think of no content in the biscuit that would have caused a decrease in this individual cardiovascular risk factor other than the probiotic. This is of particular interest to us because there has been little experimentation investigating the influence of diet on this lipid-protein complex. Since its discovery by Berg in 1963, high levels of blood lipoprotein(a) have been shown to be associated with heart disease ${ }^{18-20}$ and, to date, niacin appears to be the only effective treatment in the control of lipoprotein(a) concentrations ${ }^{21-23}$.

Biscuits are typically high in both fat and sugar and have been identified as a food contributing to negative health. They are consumed by a large part of the UK population and are popular with both children and adults. Biscuits are therefore a good choice, and one example of many popular food products that can be healthily redesigned and consumed favourably as opposed to discouraged in society. We are aware of the food industry's attempts to modify the food content of certain high-risk foods to make them more acceptable to the ever-increasing health demands of society. To our knowledge, no food has been as vigorously changed as the biscuit we describe 
Table 1 Homocysteine and lipoprotein(a) concentrations before (pre) and after (post) consumption of modified (mod) and nonmodified (non-mod) biscuits

\begin{tabular}{lcccc}
\hline Variable & $\begin{array}{c}\text { Pre } \\
(\mathrm{mod})\end{array}$ & $\begin{array}{c}\text { Post } \\
(\mathrm{mod})\end{array}$ & $\begin{array}{c}\text { Pre } \\
(\text { non-mod })\end{array}$ & $\begin{array}{c}\text { Post } \\
\text { (non-mod) }\end{array}$ \\
\hline $\begin{array}{l}\text { Homocysteine } \\
\left(\mu \mathrm{I}^{-1}\right)\end{array}$ & $15.3 \pm 6.9^{*}$ & $11.2 \pm 4.3^{*}$ & $12.4 \pm 5.9$ & $11.9 \pm 1.5$ \\
Lipoprotein & $193.5 \pm 76.8^{\star}$ & $149.6 \pm 27.5^{\star}$ & $251.5 \pm 97.9$ & $259 \pm 103$ \\
$(\mathrm{a})\left(\mathrm{mg} \mathrm{I}^{-1}\right)$ & & & & \\
\hline
\end{tabular}

Values are means \pm standard deviation.

* Significant at $P<0.05$.

whilst still maintaining its taste and attractiveness to the consumer.

Table 1 presents the results for homocysteine and lipoprotein(a) concentrations $(n=10)$ following a $12 \mathrm{~h}$, randomly assigned, fasting study when the modified biscuits were compared with the non-modified product. Significant reductions $(P<0.05)$ in concentrations were observed after consumption of the modified biscuit only. Pre indicates blood values prior to biscuit administration. Post indicates blood values following the intervention.

\section{Wyndham J Boobier*, Julien S Baker and Bruce Davies}

Health and Exercise Science Research Unit

School of Applied Sciences

University of Glamorgan, Pontypridd, CF37 1DL, UK

*Email: wboobier@glam.ac.uk

DOI: $10.1079 /$ PHN2005832

\section{References}

1 Keys A. Coronary heart disease in seven countries. Circulation 1970; 41: 11-211.

2 Gotto AM Jr. High density lipoprotein cholesterol and triglycerides as therapeutic targets for preventing and treating coronary artery disease. American Heart Journal 2002; 144: S33-S42.

3 Yudkin J, Kang SS, Bruckdorfer KR. Effects of high dietary sugar. British Medical Journal 1980; 281: 1396.

4 Jeppesen J, Hein HO, Saudicani P, Gyntelberg F. High triglycerides/low high-density lipoprotein cholesterol, ischemic electrocardiogram changes, and risk of ischemic heart disease. American Heart Journal 2003; 145: 103-8.

5 Zieden B, Kaminskas A, Kristenson M, Olsson AG, Kucinskiene $Z$. Long chain polyunsaturated fatty acids may account for higher low-density lipoprotein oxidation susceptibility in Lithuanian compared to Swedish men. Scandinavian Journal of Clinical and Laboratory Investigation 2002; 62: 307-14.

6 Nisbett EF, Rossiter AH, Miller AR, Thacker D. Fat is short dough biscuits. Flour Milling and Baking Research Association 1986; (2): 63-77.
7 Davis MM, Jones DW. The role of lifestyle management in the overall treatment plan for prevention of management of hypertension. Seminars in Nephrology 2002; 22: 35-43.

8 Franklin SS, Khan SA, Wong ND, Larson MG, Levy D. Is pulse pressure useful in predicting risk factors for coronary heart disease? The Framingham Heart Study. Circulation 1999; 100: $354-60$.

9 Van den Hoogen PC, Feskens EJ, Nagelkerke NJ, Menotti A, Nissinen A, Kromhout D. The relation between blood pressure and mortality due to coronary heart disease among men in different parts of the world. Seven Countries Study Research Group. New England Journal of Medicine 2000; 342: $1-8$.

10 He J, Ogden LG, Vupputuri S, Bazzano L, Loria C, Whelton PK. Dietary sodium intake and myocardial infarction. Journal of the American Medical Association 1999; 282: 2027-34.

11 Krauss RM, Deckelbaum RJ, Ernst N, Fisher E, Howard BV, Knopp RH, et al. Dietary guidelines for healthy American adults: a statement for health professionals from the nutrition committee, American Heart Association. Circulation 1996; 94: 1795-800.

12 Pietinen P, Rimm EB, Korhonen P, Hartman AM, Willett WC, Albanes D, et al. Intake of dietary fibre and risk of coronary heart disease in a cohort of Finnish men. The alphaTocopherol Beta-Carotene Prevention Study. Circulation 1996; 94: 2720-7.

13 Rimm EB, Ascherio A, Giovannucci E, Spiegelman D, Stampfer MJ, Willett WC. Vegetable, fruit and cereal fibre intake and risk of coronary heart disease among men. Journal of the American Medical Association 1996; 275: 447-51.

14 McCully KS. Vascular pathology of homocysteinemia: implications for the pathogenesis of arteriosclerosis. American Journal of Pathology 1969; 56: 111-28.

15 Klerk M, Verhoef P, Verbruggen B, Schouten EG, Blom HJ, Bos GM, et al. Effect of homocysteine reduction by B vitamin supplementation on marker of clotting activation. Thrombosis and Haemostasis 2002; 88: 230-5.

16 Billion S, Tribout B, Cadet E, Queinnec C, Rochette J, Wheatley $\mathrm{P}$, et al. Hyperhomocysteinemia, folate and vitamin $\mathrm{B}_{12}$ in unsupplemented haemodialysis patients: effect of oral therapy with folic acid and vitamin $\mathrm{B}_{12}$. Nephrology, Dialysis, Transplantation 2002; 17: 455-61.

17 Genest F Jr. Homocysteine: to screen and treat or wait and see? Canadian Medical Association Journal 2000; 163: $37-8$.

18 Hoefler G, Harnoncourt F, Pashcke E, Mirtl W, Pfeiffer KH, Kostner GM. Lipoprotein(a) Lp(a). A risk factor for myocardial infarction. Arteriosclerosis 1988; 8: 394-401.

19 Sandkamp M, Funke H, Schulte EK, Assman G. Lipoprotein(a) is an independent risk factor for myocardial infarction at a young age. Clinical Chemistry 1990; 36: 20-3.

20 Rosengren A, Wilhelmsen L, Eriksson E, Risberg B, Wedel H. Lipoprotein (a) and coronary heart disease: a prospective case control study in a general population sample of middleaged men. British Medical Journal 1990; 301: 1248-51.

21 Batiste MC, Schaefer EJ. Diagnosis and management of lipoprotein abnormalities. Nutrition in Clinical Care 2002; 5: 115-23.

22 Pieper JA. Understanding niacin formulations. American Journal of Managed Care 2002; 8: S308-14.

23 Pan J, Van JT, Chan RL, Lin M, Charles MA. Extended-release niacin treatment of the atherogenic lipid profile and lipoprotein (a) in diabetes. Metabolism 2002; 52: 1120-7. 